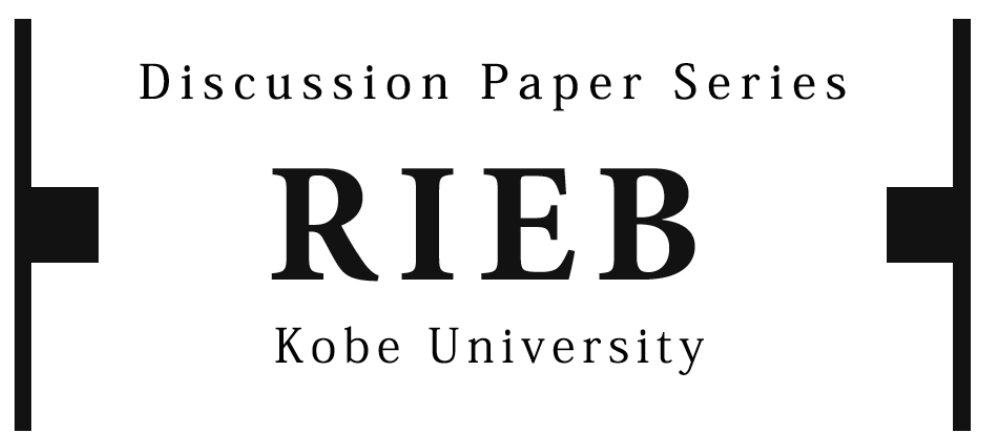

DP2016-30

\title{
Dynamics of Rural Transformation and Poverty and Inequality in Asia and the Pacific*
}

\author{
Katsushi S. IMAI \\ Raghav GAIHA \\ Fabrizio BRESCIANI
}

Revised February 5, 2019

* The Discussion Papers are a series of research papers in their draft form, circulated to encourage discussion and comment. Citation and use of such a paper should take account of its provisional character.

In some cases, a written consent of the author may be required.

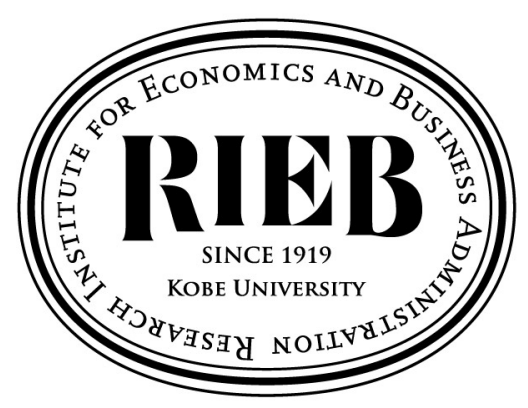

Research Institute for Economics and Business Administration

Kobe University

2-1 Rokkodai, Nada, Kobe 657-8501 JAPAN 


\title{
Dynamics of Rural Transformation and Poverty and Inequality in Asia and the Pacific
}

Katsushi S. Imai, The Department of Economics, The University of Manchester and RIEB, Kobe University

Raghav Gaiha, Global Development Institute, University of Manchester and Population Studies Centre, University of Pennsylvania

Fabrizio Bresciani, Asia and the Pacific Division of International Fund for Agricultural Development

Date: This version: $5^{\text {th }}$ February 2019

\begin{abstract}
This chapter analyses the dynamics of transformation which has taken place in rural areas of Asia and the Pacific, with a focus on their effects on poverty and inequality in both rural and urban areas. It draws upon an up-to-date country panel dataset covering 21 countries in 1960-2014 in the region. We find that transformation of the agricultural sector in rural areas in terms of commercialisation and product diversity has dynamically increased agricultural value added per capita and its growth rate, and consequently reduced both rural and urban poverty significantly in our sample countries. The effect of agricultural transformation in reducing child malnutrition is also corroborated, while inequality in rural areas is reduced only at the initial stage of development of agriculture in low income countries. Our analysis also confirms that agricultural transformation, in terms of commercialisation and product diversification, promotes total factor productivity (TFP) with lags, which reduces both rural and urban poverty significantly. Acceleration of agricultural transformation, for instance, through the policies promoting rural infrastructure or facilitating the synergy between public and private investment in rural areas, is likely to reduce rural and urban poverty with a caveat that the inequality may increase as the process deepens.
\end{abstract}

Key Words: Rural Transformation, Agricultural Transformation, Agricultural Productivity, Poverty, Inequality, Asia

JEL Codes: C23, I32, Q18

Corresponding Author: Katsushi S. Imai (Dr.) 3.066 Arthur Lewis Building, Department of Economics, School of Social Sciences, University of Manchester, Oxford Road, Manchester M13 9PL UK; Telephone: +44-(0)161-275-4827, Fax: +44-(0)161-275-4812 Email: Katsushi.Imai@manchester.ac.uk. 


\section{Dynamics of Rural Transformation and Poverty and Inequality in Asia and the Pacific ${ }^{1}$}

(forthcoming as Chapter 15 in Handbook of Poverty, edited by Bent Greve, Routledge, 2019)

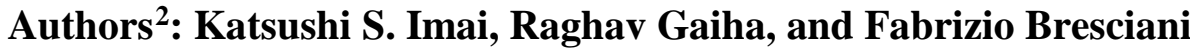

\subsection{Introduction}

While many countries in Asia - in particular, in East Asia and South Asia - have experienced rapid economic growth during the last decade, its rural areas have experienced structural transformation, induced by globalisation, industrialisation, and urbanisation. Despite economic growth, a large section of people in rural areas still suffer from abject poverty and malnutrition, implying that economic growth has bypassed many (IFAD, 2016).

The growth-inequality relationship is intricately associated with the relationship between structural transformation and inequality. If labour productivity in rural areas rises at a slower rate than in urban areas, the disparity between rural and urban areas will widen. Rural-tourban migration, however, could have an offsetting effect if migration is temporary and benefits more rural households than before during the urbanisation process. While many of the rural regions have benefited from more integrated wholesale and retailing networks and supply chains (e.g. expansion of supermarket chains to rural areas, horticulture or contract

\footnotetext{
${ }^{1}$ This study is funded by Asia and the Pacific Division (APR), IFAD (International Fund for Agricultural Development). The authors are grateful for valuable comments from one internal reviewer at IFAD, Kostas Stamoulis (FAO), Andrea Cattaneo (FAO), and other participants in 'Expert Consultation on Focusing Agricultural and Rural Development Research and Investment on Achieving SDGs 1 and 2: A joint initiative of FAO, IFAD, CGIAR, and the World Bank: In partnership with the EU' in Rome in January 2017. The second author acknowledges valuable advice from David Bloom. The authors also thank Bilal Malaeb for his advice on data processing and econometric estimations. The opinions expressed in this publication are those of the authors and do not necessarily represent those of IFAD.

${ }^{2}$ Katsushi Imai is Associate Professor in Economics at the Department of Economics, the University of Manchester. Raghav Gaiha is Honorary Professorial Research Fellow at Global Development Institute, University of Manchester and Visiting Scholar at Population Studies Centre, University of Pennsylvania. Fabrizio Bresciani is Lead Economist at Asia and the Pacific Division of International Fund for Agricultural Development. Contact Author: Katsushi S. Imai (Dr.) 3.066 Arthur Lewis Building, Department of Economics, School of Social Sciences, University of Manchester, Oxford Road, Manchester M13 9PL UK; Telephone: +44-(0)161-275-4827, Fax: +44-(0)161-275-4812 Email: Katsushi.Imai@manchester.ac.uk.
} 
farming with multinational firms, agricultural production and sales more integrated with urban regions and developed world, and diversification of rural non-farm sector), whether it decreases inequality is unclear and depends on geographical distributions of these networks. If structural transformation increases overall productivity and outputs in rural areas, the structural transformation would reduce income inequality at national levels. However, if for example backward regions (e.g. mountainous areas in North-East India or north mountain regions in Vietnam) are left out of structural transformation, it is likely to increase inequality. One of the main objectives of this chapter is to understand better whether inequality and poverty have increased as the country experienced structural transformation and the underlying reasons.

Of particular importance are farm and non-farm linkages and whether higher rural incomes are in part due to more diversified livelihoods and the emergence of high-value chains and the extent to which these have reduced rural-urban disparities and dampened migration. Apart from easier access to credit in order to strengthen farm/non-farm linkages, and smallholder participation in high-value chains, other major policy concerns relate to whether remittances - sent either from internal migrants from rural to urban areas or international migrants - could be allocated to more productive uses in rural areas, through higher risk-weighted returns, and whether returns could be enhanced in agriculture and rural non-farm activities while risks are reduced.

This study examines how the structural transformation in rural Asia and the Pacific dynamically influences poverty and inequality by applying econometric models to the crosscountry panel data to capture the dynamic relationships among rural/agricultural transformations, growth/productivity, and poverty/inequality.

The rest of this chapter is organised as follows. After reviewing the concepts of agricultural transformation in Section 15.2, we will discuss three different measures of 
agricultural transformation in Section 15.3. Section 15.4 first outlines an empirical model and discusses the results. Section 15.5 is devoted to concluding observations with policy implications.

\subsection{Concepts and measurement of rural or agricultural transformation ${ }^{3}$}

While 'rural transformation' $(R T)$ is a broader concept than ‘agricultural transformation' $(A T)$ due to the non-negligible share of non-agricultural sector, we will primarily focus on the transformation of the agricultural sector, drawing and building upon Dawe (2015). While Dawe discusses in detail transformation of the agricultural sector of middle-income Asian countries, ${ }^{4}$ he does not provide a clear definition of 'agricultural transformation'. Citing Reardon and Timmer (2014), Dawe first discusses 'the structural transformation of economies' and then argues that $A T$ is one of the five key transitions as a result of sustained income, that is, (i) urbanization, (ii) growth of the rural non-farm economy, (iii) dietary diversification, (iv) a revolution in supply chains and retailing; and (v) transformation of the agricultural sector. Consistent with the last transition, he argues that '(t) here are at least three key changes that might be expected to occur during the agricultural transition: mechanization, increases in farm size, and crop/product diversification' (Dawe, p.5, emphasis added). Dawe then reviews some statistical evidence to show how mechanization took place, farm size increased, and crop diversification took place in middle-income Asian countries, China, Indonesia, Malaysia, the Philippines, Thailand, and Vietnam. However, as Dawe did not define $A T$ clearly, it is not clear what sort of transformation is envisaged. For instance, farm size did not increase uniquely in different areas of these countries (Figures 14-15 on pp. 2122 in Dawe), but it is not clear whether this heterogeneity implies AT took place in some

\footnotetext{
${ }^{3}$ This sub-section draws upon Imai (2017) where the analysis has been carried out for all developing countries using a similar model.

${ }^{4}$ It is taking place in low income countries too but not quite as visibly.
} 
parts of the country and did not in other parts ${ }^{5}$. It is not clear either whether crop/product diversification took place consistently across these countries (e.g. Malaysia became more specialised in oil crops, as illustrated in Figure 17).

In this chapter, we define $A T$ as: "fundamental changes in agricultural production and smallholders” livelihood in a developing economy as it is globalised, which are characterised as the three changes: (i) mechanisation and new agricultural technologies, (ii) changing cropping patterns with declining shares of grains and rising shares of non-grains, in particular, fruits, vegetables, dairy products, and meat, and (iii) new organisational forms (contract farming) as well as land and machinery rental markets that would enable smallholders to benefit from economies of scale (Barrett et al. 2012). While Dawe (2015) focuses mainly on the first and partly the second aspect, our study captures $A T$ as a broader and more complex process covering the remaining aspects.

\subsection{Measures of agricultural transformation $(A T)$}

While AT should be defined from a broader perspective, it is not feasible to use a measure covering all the above aspects in AT. We will thus construct three measures, commercialization index, agricultural openness and production diversification to capture salient features of $A T$.

\section{Commercialization Index}

To construct our commercialization index, we use the production file (the value of agricultural production) (http://faostat.fao.org/site/613/default.aspx\#ancor) as well as the price file (http://faostat.fao.org/site/703/default.aspx\#ancor) in FAOSTAT to capture the

\footnotetext{
${ }^{5}$ The overall trend in Asia has been that of declining farm size. For example, in Bangladesh farm size declined drastically from 1.4 ha in 1976/77 to 0.3 ha in 2005. Similarly, India, Pakistan and the Philippines also experienced significant declines in average farm size over time (Thapa, 2016).
} 
extent to which processed agriculture and livestock products are produced in total agricultural and livestock production. The values are adjusted based on producer prices in the international US\$ (PPP) in 2004-2006. More specifically, the index is defined for all the years in the sample, 1960-2014, as follows.

\section{Commercialisation Index $=(C+L) /(C+L+C P+L P)$}

where

$\mathrm{C}=$ [Monetary value of Production for Aggregate Crops Processed (beer, cotton lint, cotton seed, margarine, molasses, oil (such as coconut oil, cottonseed oil, ground nut oil, linseed oil), palm kernels, sugar raw centrifugal, wine)]

$\mathrm{L}=$ [Monetary value of Production for Aggregate livestock processed (butter, cheese, milk, lard, yogurt)]

$\mathrm{CP}=$ [Monetary value of Production for Aggregate Crop Primary $]$

$\mathrm{LP}=$ [Monetary value of Production for Aggregate Livestock Primary]

This measure is based on the assumption that processed agricultural products are more likely to be commercialized. For instance, we assume that farmers producing maize oil are more commercialised than those producing maize. While this will be a reasonable assumption, it is noted that our measure captures only a part of the process where agricultural production of the country gets commercialised. This index reflects the overall structure of agricultural production in terms of whether the agricultural crops or livestock are sold as raw crops or processed crops. However, the index does not capture the increase in the production of, for instance, raw vegetables or plantation crops such as rubber, pineapple, bananas, which tend to be well commercialised. To partly overcome possible limitations of the index, we will use alternative indices.

We have examined whether our commercialisation index is correlated with the value added in food, beverage, and tobacco production. As expected, they are positively correlated with the correlation coefficient 0.37 (with p-value 0.0000) for the whole of Asia. Figure 15.1 shows the overall association between our commercialisation index and the value added in food, beverage, and tobacco production. At low levels of food production, our 
commercialisation index can be high or low with high variance, there is then a positive relationship at a slightly higher level of food production, and above a certain threshold, the commercialisation index gets almost flat.

Figure 15.1 The relation between the Commercialisation index and the per capita value added in food, beverage, and tobacco production

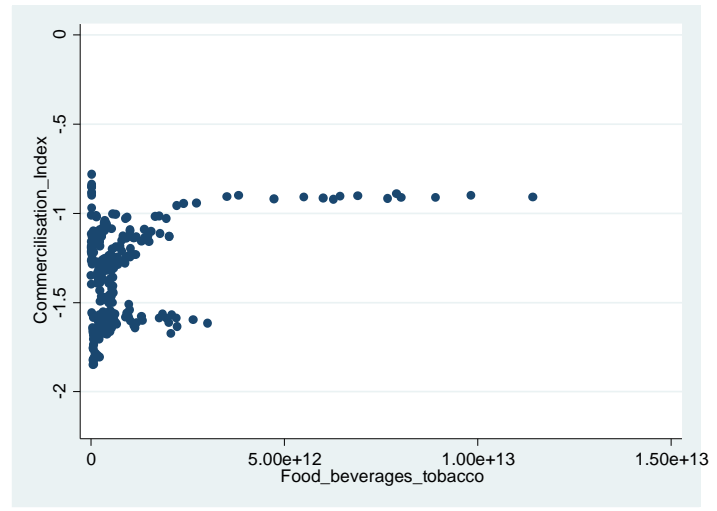

We have also examined the relationship between the commercialisation index and the index of mechanisation. Given that only crude measures are available from FAOSTAT, we have used the number of tractors per land of $100 \mathrm{~km}^{2}$. These are positively and significantly correlated with an overall correlation coefficient of 0.53 for the entire Asia. Figure 15.2 confirms the positive correlation between the two variables.

Figure 15.1 The relation between the Commercialisation index and the per capita value added in food, beverage, and tobacco production

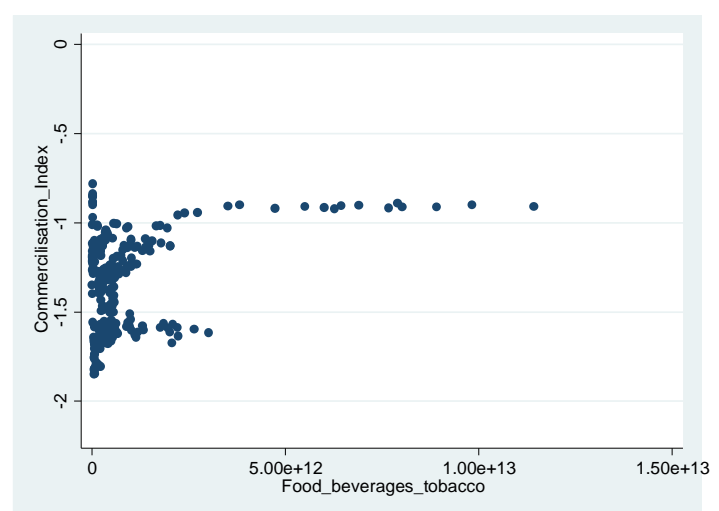

\section{Agricultural Openness}


Agricultural trade openness is simply defined as [aggregate agricultural export]/ [agricultural value added]. Agricultural export is based on the trade file of FAOSTAT (http://faostat.fao.org/site/535/default.aspx\#ancor) (in the international US\$ (PPP) in 20042006). The agricultural exports include food and non-food agricultural products. Here we do not include agricultural imports because the import of agricultural crops, while influenced by globalisation and influencing agricultural production systems to some extent, would mainly be demand-driven and does not reflect the transformation of the agricultural production systems we discussed earlier. ${ }^{6}$ On the contrary, higher share of agricultural export tends to reflect more integration of agricultural production into the rest of the world and is deemed a more suitable proxy for the agricultural transformation. The agricultural value added is based on World Development Indicators (WDI) published and released in 2016. As the agricultural sector of the country gets structurally transformed (e.g. through mechanisation or contract farming), the relative competitiveness of the agricultural product improves and the agricultural openness index tends to be higher.

\section{Product Diversification}

We propose to use the diversity index at the country level drawing upon Remans et al. (2014) who used an index called 'Shannon Entropy diversity metric' to capture the production diversity at the country level using FAOSTAT. The index can be defined as:

$H^{\prime}=-\sum_{i=1}^{R} p_{i} \ln p_{i}$

where $R$ is the number of agricultural products and $p_{i}$ is the share of production for the item $i$, available from FAOSTAT. The production share, $p_{i}$, is defined in terms of the monetary value at a local price for each product, $i$. If the country produces more agricultural products,

\footnotetext{
${ }^{6}$ We could construct the share of the input import in the input consumption, but the data on the fertilizer and pesticides import are available only after 2002 from FAOSTAT and unsuitable for the present purpose.
} 
including processed and unprocessed crops and the monetary values of products are more evenly divided among different items, the diversity index, $H^{\prime}$, takes a larger value. On the contrary, if the country produces a smaller number of agricultural products and the monetary value of one or two specific products is large, $H^{\prime}$ is smaller. Figure 15.2 indicates that our product diversification index is highly correlated with the share of non-cereal production. The correlation coefficient for all the sample 21 countries in Asia is 0.41 - except the top end (above 90\%) of non-cereal share where these two variables are negatively correlated for Malaysia. The correlation is stronger for the countries in South Asia with the correlation coefficient 0.74 (p-value 0.0000) and weaker for East and South East Asia with the correlation coefficient 0.22 (p-value 0.0003 ).

Figure 15.3 The relation between the product diversification index and the share of value of non-cereal production in the total value of agricultural production 


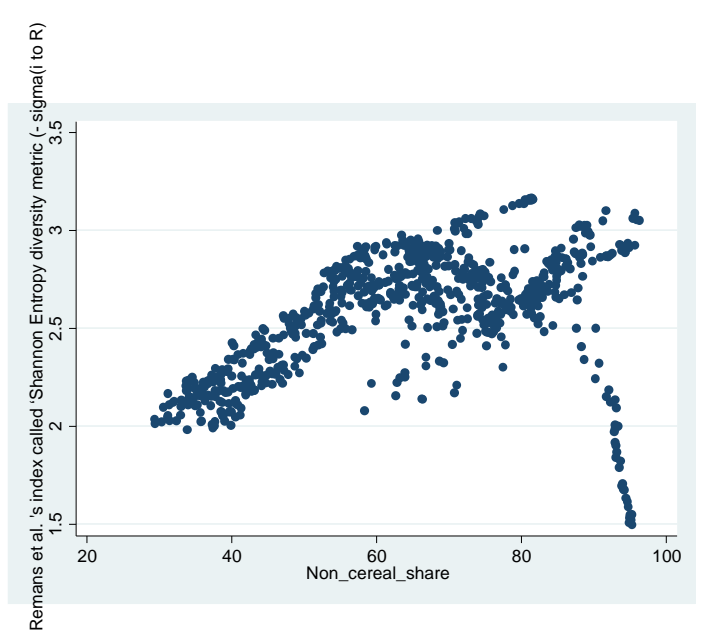

15.3. Data, Empirical Models and Results

\section{Data}

Our empirical analysis is based mostly on FAOSTAT (http://faostat.fao.org/), World Development Indicators (WDI) 2016 (http://data.worldbank.org/data-catalog/worlddevelopment-indicators), the World Bank poverty database (PovCalNet, http://iresearch.worldbank.org/PovcalNet/), World Bank World Governance Indicators (WGI) (http://data.worldbank.org/data-catalog/worldwide-governance-indicators), and Quality of Government Dataset (http://qog.pol.gu.se/data). The agricultural Total Factor Productivity estimates are taken from Fuglie (2012 and 2015). Table 1 summarizes the main variables we will use in the econometric estimations.

Table 15.1 Descriptive Statistics of Variables

\begin{tabular}{|c|c|c|c|c|c|c|}
\hline Variable & Definition (Data source) & Obs & Mean & Std. Dev. & Min & $\operatorname{Max}$ \\
\hline \multicolumn{7}{|l|}{ Dependent Variables } \\
\hline dlogagrivapc & $\begin{array}{l}\text { Annual growth of agricultural value added per } \\
\text { capita (WDI) } \\
\text { Agricultural TFP Index (log) based on FAOSTAT }\end{array}$ & 748 & 0.008 & 0.064 & -0.692 & 0.341 \\
\hline logagTFP & (Fuglie, 2012 and 2015). & 1,272 & 4.606 & 0.214 & 3.784 & 5.323 \\
\hline dlogagTFP & $\begin{array}{l}\text { Growth rate of agricultural TFP. } \\
\text { Log of Poverty Headcount Ratio based on }\end{array}$ & 1,272 & 0.0092 & 0.035 & -0.309 & 0.324 \\
\hline povertyhc200 & $\begin{array}{l}\text { US } \$ 2.00 \text { (PPP at 2005). (WDI) } \\
\text { Poverty Headcount Ratio based on US } \$ 1.25\end{array}$ & 153 & 3.695 & 1.064 & -2.813 & 4.583 \\
\hline povertyhc200_raw & $\begin{array}{l}\text { (PPP in 2005). (WDI) } \\
\text { Log of Poverty Headcount Ratio based on }\end{array}$ & 153 & 53.773 & 26.981 & 0.060 & 97.810 \\
\hline povertyhc190 & $\begin{array}{l}\text { US } \$ 1.90 \text { (PPP at 2011). (WDI) } \\
\text { Poverty Headcount Ratio based on US } \$ 1.90\end{array}$ & 1,155 & 0.611 & 1.634 & 0.000 & 5.541 \\
\hline Poverty190_raw & $\begin{array}{l}\text { (PPP in 2011). (WDI) } \\
\text { Log of Poverty Headcount Ratio based on }\end{array}$ & 1,155 & 20.584 & 57.079 & 1.000 & 255.000 \\
\hline povertyhc310 & US\$3.10 (PPP at 2011). (WDI) & 1,155 & 0.670 & 1.758 & 0.000 & 5.765 \\
\hline povertyhc310_raw & $\begin{array}{l}\text { Poverty Headcount Ratio based on US } \$ 3.10 \\
\text { (PPP in 2011). (WDI) }\end{array}$ & 1,155 & 27.392 & 74.400 & 1.000 & 319.000 \\
\hline
\end{tabular}




\begin{tabular}{|c|c|c|c|c|c|c|}
\hline \\
\hline Gini & Gini coefficient (in log) & 191 & 3.594 & 0.156 & 3.248 & 4.113 \\
\hline Gini_raw & Gini coefficient (in raw value) & 191 & 36.811 & 5.824 & 25.740 & 61.100 \\
\hline logweight_age & $\begin{array}{l}\text { (\% of children under } 5 \text { ) } \\
\text { malnutrition prevalence, weight for age, (\% of }\end{array}$ & 148 & 3.268 & 0.677 & 1.224 & 4.209 \\
\hline weight_age & children under 5) & 126 & 31.248 & 16.013 & 3.400 & 67.300 \\
\hline epov_h_rur & & 110 & 24.579 & 21.794 & 0.000 & 83.500 \\
\hline epov_gap_rur & $\begin{array}{l}\text { extreme rural poverty gap ( } \% \text { of rural population } \\
\text { under } \$ 1.25 \text { a day) (SKD, IFAD) } \\
\text { extreme rural squared poverty gap ( } \% \text { of rural }\end{array}$ & 110 & 7.067 & 8.408 & 0.000 & 57.600 \\
\hline epov_gap2_rur & population under $\$ 1.25$ a day) (SKD, IFAD) & 110 & 2.994 & 5.116 & 0.000 & 45.560 \\
\hline gini_rur & $\begin{array}{l}\text { Gini coefficient in rural areas (SKD, IFAD) } \\
\text { moderate rural poverty headcount (\% of rural }\end{array}$ & 110 & 32.669 & 5.886 & 23.850 & 63.960 \\
\hline mpov_h_rur & population under $\$ 2$ a day) (SKD, IFAD) & 110 & 47.900 & 30.966 & 0.190 & 93.040 \\
\hline mpov_gap_rur & $\begin{array}{l}\text { moderate rural poverty gap ( } \% \text { of rural } \\
\text { population under } \$ 2 \text { a day) (SKD, IFAD) } \\
\text { moderate rural squared poverty gap ( } \% \text { of rural }\end{array}$ & 110 & 18.367 & 14.839 & 0.010 & 69.030 \\
\hline mpov_gap2_rur & $\begin{array}{l}\text { population under } \$ 2 \text { a day) (SKD, IFAD) } \\
\text { extreme urban poverty headcount ( } \% \text { of urban }\end{array}$ & 110 & 9.163 & 9.031 & 0.000 & 57.020 \\
\hline epov_h_urb & $\begin{array}{l}\text { population under } \$ 1.25 \text { a day) (SKD, IFAD) } \\
\text { extreme urban poverty gap ( } \% \text { of urban }\end{array}$ & 109 & 14.586 & 15.394 & 0.000 & 62.010 \\
\hline epov_gap_urb & $\begin{array}{l}\text { population under } \$ 1.25 \text { a day) (SKD, IFAD) } \\
\text { extreme urban squared poverty gap ( } \% \text { of } \\
\text { urban population under } \$ 1.25 \text { a day) (SKD, }\end{array}$ & 108 & 4.218 & 6.623 & 0.000 & 51.970 \\
\hline epov_gap2_urb & IFAD) & 107 & 1.878 & 4.906 & 0.000 & 47.080 \\
\hline gini_urb & $\begin{array}{l}\text { Gini coefficient in urbn areas } \\
\text { moderate urban poverty headcount (\% of urban }\end{array}$ & 107 & 35.963 & 6.102 & 24.600 & 71.700 \\
\hline mpov_h_urb & $\begin{array}{l}\text { population under } \$ 2 \text { a day) } \\
\text { moderate urban poverty gap ( } \% \text { of urban }\end{array}$ & 107 & 31.949 & 25.782 & 0.030 & 86.640 \\
\hline mpov_gap_urb & $\begin{array}{l}\text { population under } \$ 2 \text { a day) } \\
\text { moderate urban squared poverty gap ( } \% \text { of }\end{array}$ & 106 & 11.229 & 11.266 & 0.000 & 57.410 \\
\hline mpov_gap2_urb & & 106 & 5.478 & 7.114 & 0.000 & 51.880 \\
\hline epov_h_rur & population under $\$ 1.25$ a day) & 110 & 24.579 & 21.794 & 0.000 & 83.500 \\
\hline \multicolumn{7}{|c|}{ Explanatory Variables } \\
\hline $\begin{array}{l}\text { Commercialization } \\
\text { Index }\end{array}$ & Commercialization Index ${ }^{\star} 1$ (FAOSTAT) & 861 & -1.165 & 0.411 & -2.202 & -0.245 \\
\hline agopenness & $\begin{array}{l}\text { [aggregate agricultural export]/ [agricultural } \\
\text { value added] (FAOSTAT) }\end{array}$ & 639 & -8.682 & 2.526 & -13.535 & 5.107 \\
\hline productdiversity & $\begin{array}{l}\text { Production Diversity Index *2 (FAOSTAT) } \\
\text { Aggregate institutional quality (average of voice } \\
\text { and accountability, government effectiveness, } \\
\text { regulatory quality, rule of law and control of }\end{array}$ & 861 & 0.943 & 0.128 & 0.403 & 1.152 \\
\hline Political Stability & Political stability and absence of violence (WGI). & 388 & -0.545 & 0.857 & -2.810 & 1.330 \\
\hline Land & $\begin{array}{l}\text { Land area is a country's total area (WDI). } \\
\text { Population density (people per sq. } \mathrm{km} \text { of land }\end{array}$ & 1,155 & 3.815 & 1.166 & 0.000 & 5.118 \\
\hline Population_density & $\begin{array}{l}\text { area). } \\
\text { CPIA rating of macroeconomic management }\end{array}$ & 1,155 & 6.302 & 1.641 & 0.000 & 7.636 \\
\hline Fragility Index & and coping with fragility (1=low to 6=high) & 1,176 & 7.618 & 1.193 & 1.000 & 8.000 \\
\hline $\begin{array}{l}\text { Openness } \\
\text { Ethnic }\end{array}$ & Imports and exports (value added)/GDP (WDI). & 1,155 & 4.543 & 2.846 & 0.000 & 7.146 \\
\hline fractionalization & Ethnic fractionalization Index *4 & 697 & -1.059 & 0.706 & -3.091 & -0.308 \\
\hline lab_with_secondary & Labour force with secondary education & 1,155 & 0.150 & 0.706 & 0.000 & 5.209 \\
\hline Riskinland & The degree whether country is landlocked & 455 & -1.856 & 1.722 & -4.605 & 0.000 \\
\hline primary_yrs & Average years of schooling at primary school & 1,155 & 3.700 & 1.522 & 1.000 & 7.000 \\
\hline second_years & Average years of schooling at secondary school & 1,155 & 3.740 & 1.502 & 1.000 & 6.000 \\
\hline populati__14 & Population below 14 years old & 1,155 & 1495.045 & 405.122 & 205.000 & 2116.000 \\
\hline populati 65_ & Population above 14 years old & 1,155 & 1225.122 & 366.004 & 2.000 & 2080.000 \\
\hline SA & Whether in South Asia & 1,155 & 0.286 & 0.452 & 0.000 & 1.000 \\
\hline EAP & Whether in East Asia and Pacific & 1,155 & 0.524 & 0.500 & 0.000 & 1.000 \\
\hline
\end{tabular}




\begin{tabular}{|c|c|c|c|c|c|c|}
\hline LOWI & Whether in low income countries & 588 & 0.413 & 0.493 & 0.000 & 1.000 \\
\hline LOWERMI & Whether in lower middle income countries & 588 & 0.412 & 0.493 & 0.000 & 1.000 \\
\hline UPPERMI & $\begin{array}{l}\text { Whether in upper middle income countries } \\
\text { Income class (0 for low income countries; } 1 \text { for } \\
\text { lower middle income countries; } 2 \text { for upper }\end{array}$ & 588 & 0.094 & 0.291 & 0.000 & 1.000 \\
\hline ICLASS & $\begin{array}{l}\text { middle income countries) } \\
\text { Adjusted GNI per capita based on World Atlas } \\
\text { Method (adjusting for local and world price and }\end{array}$ & 540 & 0.652 & 0.657 & 0.000 & 2.000 \\
\hline Gnipcadj & exchange rate fluctuations). & 827 & 1189.746 & 1596.007 & 50.000 & 11850.000 \\
\hline Logagriemp & Log of agricultural employment & 192 & 3.057 & 0.732 & 0.182 & 4.388 \\
\hline $\mathrm{gA}$ & Annual growth rate of agricultural output & 119 & -0.086 & 0.721 & -3.367 & 3.217 \\
\hline Logmanuemp & Log of manufacturing employment & 209 & 2.795 & 0.365 & 0.993 & 3.384 \\
\hline $\mathrm{gN}$ & Annual growth rate of non-agricultural output & 155 & 0.018 & 0.116 & -0.817 & 0.615 \\
\hline Logseremp & Annual growth rate of service output & 209 & 3.443 & 0.325 & 2.573 & 4.009 \\
\hline gS & Annual growth rate of service output & 155 & 0.016 & 0.064 & -0.274 & 0.322 \\
\hline
\end{tabular}

Notes: *1. This is defined as $\{$ [Aggregate Crops Processed (beer, cotton lint, cottonseed, margarine, molasses, oil (such as coconut oil, cottonseed oil, ground nut oil, linseed oil), palm kernels, sugar raw centrifugal, wine)] $+[$ Aggregate livestock processed (butter, cheese, milk, lard, yogurt)]\} I\{[Aggregate Crops Processed (same as above)] $+[$ Aggregate livestock processed (same as above)] + [(Raw) Crops ]+ [Aggregate Livestock Primary] + [Aggregate Live Stock, Primary (eggs, skins, wool)]\}

*2. The index can be defined as $H^{\prime}=-\sum_{i=1}^{R} p_{i} \ln p_{i}$ where $R$ is the number of items of agricultural products and $p_{i}$ is the share of production for item $i$, available from FAOSTAT.

*3. Presents agricultural TFP indexes (based year 1992=100) over 1961-2012 using primarily FAO data, supplemented in some cases by national statistics. The output is FAO gross agricultural output (GAO) smoothed using the Hodrick-Prescott Filter (Lambda $=6.25$ ). Input growth is the weighted-average growth in the quality-adjusted land, labour, machinery power, livestock capital, synthetic NPK fertilizers, and animal feed, where weights are input (factor) cost shares. Agricultural TFP indexes are estimates by country and for groups of countries aggregated by geographic region and income class ((Fuglie, 2012 and 2015).

*4. Ethnic fractionalization Index reflects the probability that two randomly selected people from a given country will not belong to the same ethnolinguistic group. The higher the number, the more fractionalized society. The definition of ethnicity involves a combination of racial and linguistic characteristics. The result is a higher degree of fractionalization than the commonly used ELF-index (see el_elf60) in, for example, Latin America, where people of many races speak the same language.

A few points are noted in Table 15.1. First, we will use both old and new World Bank poverty estimates. The first set of poverty estimates is based on the international poverty lines, US\$1.25 and US\$2.00 adjusted by 2005 PPP (purchasing power parity) (Ravallion et al., 2009). The second set of poverty estimates are the revised World Bank estimates which were released in 2016 and based on US\$1.90 and US\$3.10 adjusted by 2011 PPP (World Bank, 2016). While the latter covers more countries and more years, our study primarily focuses on the former because these have been more widely used in the literature and have served as the basis for specification of the first goal of Millennium Development Goals (MDGs) as well as Sustainable Development Goals (SDGs). We will also use rural poverty estimates in our earlier study (Imai et al., 2014) by using the rural poverty estimates which Strategy and Knowledge Department of International Fund for Agricultural Development obtained from the World Bank. These were computed by using World Bank Living Standard Measurement 
Survey (LSMS) data. Second, we have used variables capturing institutional qualities, political stability, and state fragility. Institutional qualities and political stability are based on World Governance Indicators (WGI) which have been widely used in the literature. The degree of fragility is captured by 'fragility index' proxied by the rating of macroeconomic management and coping with fragility (1=low to 6=high). High value implies low fragility. We have also tried conflict indices, but prefer the 'fragility index' as the former does not cover many countries. Third, we have used the annual growth rates of agricultural and nonagricultural real value added per capita drawing upon WDI. It is noted here that nonagricultural value added is defined as the difference between national GDP and agricultural value added and this is admittedly a rough approximation.

Due to data limitations, the panel dataset covers only 21 Asian and Pacific countries ${ }^{7}$, namely, Bangladesh, Bhutan, Cambodia, China, Fiji, India, Indonesia, Kazakhstan, Lao PDR, Malaysia, Micronesia, Fed. Sts., Nepal, Pakistan, Papua New Guinea, the Philippines, Sri Lanka, Tajikistan, Thailand, Timor-Leste, Turkmenistan, and Vietnam for 1960-2014. However, the data availability varies considerably depending on the choice of variables. As a result, only a subset of the data is used for the main econometric analyses (e.g. 15-19 countries). ${ }^{8}$

\section{An Empirical Model}

The main purpose of our empirical model is to assess the effect of agricultural transformation (AT) on poverty and inequality. To do so, we take a two-stage approach. In the first stage, we estimate the effect of $A T$ on a measure of agricultural production or agricultural productivity

\footnotetext{
${ }^{7}$ These 21 countries cover only $43 \%$ of the total 48 countries in terms of country numbers, but $84 \%$ of the population of all the countries in the region.

${ }^{8}$ We have used the data based on the maximum number of sample countries for each specification. However, when we restrict our sample to 15 countries in all the cases, the coefficient estimates of key explanatory variables are more or less same.
} 
by treating the former as endogenous. In the second stage, we estimate the effect of agricultural production on poverty and inequality. We have used the dynamic panel model, or the linear dynamic panel model based on System GMM (Blundell-Bond, 1998). Given a small $n$, a number of sample in the cross-sectional component, and a relatively small sample size, a finite sample correction has been made for the variance by using the robust estimator when two-step estimations are feasible (Windmeijer, 2005). In the second stage, a measure of poverty or inequality, disaggregated into rural and urban areas, is estimated by the agricultural production or productivity predicted in the first stage. ${ }^{9}$

\section{Results}

We will first discuss whether $A T$ influenced agricultural output. ${ }^{10}$ First, the commercialisation index positively increases agricultural value added per capita with a year's lag after taking account of the reverse causality from the latter to the former. If the share of processed agricultural and livestock products in the total agricultural and livestock products increases by $1 \%$, agricultural value added per capita tends to increase by $0.47 \%$ in the next year, other things being equal. Given the limitation of the index as a proxy for commercialisation, we can confirm that the commercialisation - in terms of the higher share of processed crops - significantly increases agricultural production. The commercialisation in terms of the higher share of processed crops also accelerates the growth of agricultural value added per capita with a time lag after taking account of the reverse causality. Second, agricultural openness does not significantly increase agricultural production or its growth rate after taking account of the reverse causality. Third, product diversity tends to increase the level of agricultural production as well as its growth rate after taking account of the reverse

\footnotetext{
${ }^{9}$ See Imai (2017) for technical details of the model.

${ }^{10}$ Tables detailing the results will be provided by the first author on request.
} 
causality. Overall, the agricultural transformation would increase agricultural value added per capita with some lag.

As an extension, we have examined the effects of agricultural transformation on TFP. The results are broadly consistent with those for agricultural value added per capita. First, a commercialisation index positively influences TFP with the first lag. Second, the effects of agricultural openness on TFP are ambiguous. Third, increased product diversity tends to improve TFP with the first lag. Turning to other variables, a higher population density tends to dampen both TFP and its growth rate, a fragility index is negatively and significantly associated with TFP, and education in terms of labour force with secondary education being positively correlated with TFP growth.

Based on the estimates of agricultural value added and agricultural productivity as a function of $A T$, we have examined the effect of agricultural transformation indices (namely, the commercialisation index and the product diversity index) on poverty or inequality. In Table 15.2 we report the results on rural and urban poverty for the international poverty thresholds, US\$1.25 and US\$2.00 (based on PPP in 2005). Here the predicted value of log agricultural value added is based on the case in which the commercialisation index is used as a main explanatory variable. Panel A shows the results for rural poverty, while Panel B for urban poverty. Panel A of Table 15.2 indicates that as the agricultural sector grows, not only will the share of poor people in rural areas be reduced, but also the severity of poverty and inequality among the rural poor will be reduced. This study is the first, to our knowledge, to show that agricultural growth has reduced poverty in rural areas, after taking into account the endogeneity of agricultural value added per capita, and using a cross-country panel data with a dynamic model. For instance, if the agricultural value added per capita increases by $1 \%$, extreme poverty headcount ratio is reduced by $2.59 \%$ points. We can infer the relative magnitude of the effect of agricultural transformation on rural poverty by combining the first 
and the second stage results. If the ratio of commercialised output to the total agricultural output increases by $1 \%$, agricultural value added per capita will increase by $0.47 \%$ next year, and this will correspond to $1.22 \%$ reduction in poverty $(=2.59 * 0.47)$ based on the mean value of rural poverty headcount (e.g. $20 \%$ to $19.76 \%=20 \%-20 * 1.22 \%$ ) next year, other things being equal (Panel A of Table 2 and Case 1 of Panel A of Table 15.2). Poverty gap, as well as its square at the poverty threshold US\$1.25 are significantly reduced as agricultural value added per capita increases (Cases 2 and 3$)^{11}$. The relative magnitudes are small, but the poverty headcount, the depth of poverty and the severity of poverty at the US\$2.00 poverty line have also been significantly reduced.

Table 15.2 Effect of Agricultural Predicted Agricultural TFP on Poverty

Panel A: Rural Poverty

\begin{tabular}{|c|c|c|c|c|c|c|}
\hline VARIABLES & Case 1 & Case 2 & Case 3 & Case 4 & Case 5 & Case 6 \\
\hline & $\begin{array}{l}\text { extreme rural } \\
\text { poverty }\end{array}$ & $\begin{array}{l}\text { extreme rural } \\
\text { poverty }\end{array}$ & $\begin{array}{l}\text { extreme rural } \\
\text { poverty }\end{array}$ & $\begin{array}{l}\text { moderate rural } \\
\text { poverty }\end{array}$ & $\begin{array}{l}\text { moderate rural } \\
\text { poverty }\end{array}$ & $\begin{array}{l}\text { moderate rural } \\
\text { poverty }\end{array}$ \\
\hline Poverty threshold & US\$1.25 & US\$1.25 & US $\$ 1.25$ & US $\$ 2.00$ & US $\$ 2.00$ & US $\$ 2.00$ \\
\hline Definition & P0 (headcount) & $\begin{array}{c}\text { P1 } \\
\text { (Gap) }\end{array}$ & $\begin{array}{c}\text { P2 } \\
\text { Gap Squared }\end{array}$ & $\begin{array}{c}\text { P0 } \\
\text { (headcount) }\end{array}$ & $\begin{array}{c}\text { P1 } \\
\text { (Gap) }\end{array}$ & $\begin{array}{c}\text { P2 } \\
\text { Gap Squared }\end{array}$ \\
\hline $\begin{array}{c}\text { Model } \\
\text { VARIABLES }\end{array}$ & $\mathrm{FE}$ & $\mathrm{FE}$ & $\mathrm{FE}$ & $\mathrm{FE}$ & $\mathrm{FE}$ & $\mathrm{FE}$ \\
\hline $\begin{array}{l}\text { plogagrivapc } \\
\text { predicted log } \\
\text { agricultural value } \\
\text { added per capita }\end{array}$ & $(0.926)$ & $\begin{array}{c}-5.544^{\star * *} \\
(1.014)\end{array}$ & $\begin{array}{c}-5.370^{\star \star \star} \\
(1.150)\end{array}$ & $-2.929 * \star *$ & $\begin{array}{c}-3.877^{\star \star \star} \\
(0.756)\end{array}$ & $\begin{array}{c}-4.527^{\star \star \star} \\
(0.863)\end{array}$ \\
\hline Observations & 80 & 80 & 78 & 80 & 80 & 80 \\
\hline R-squared & 0.5 & 0.56 & 0.565 & 0.412 & 0.497 & 0.53 \\
\hline Number of code1 & 17 & 17 & 17 & 17 & 17 & 17 \\
\hline $\begin{array}{c}\text { Hausman Test } r \\
\text { In favour of }\end{array}$ & $\mathrm{FE}$ & $\mathrm{FE}$ & FE & FE & FE & $\mathrm{FE}$ \\
\hline
\end{tabular}

\section{Panel B: Urban Poverty}

\begin{tabular}{|c|c|c|c|c|c|c|}
\hline VARIABLES & Case 1 & Case 2 & Case 3 & Case 4 & Case 5 & Case 6 \\
\hline & $\begin{array}{l}\text { extreme urban } \\
\text { poverty }\end{array}$ & $\begin{array}{l}\text { extreme urban } \\
\text { poverty }\end{array}$ & $\begin{array}{l}\text { extreme urban } \\
\text { poverty }\end{array}$ & $\begin{array}{l}\text { moderate urban } \\
\text { poverty }\end{array}$ & $\begin{array}{l}\text { moderate urban } \\
\text { poverty }\end{array}$ & $\begin{array}{l}\text { moderate urban } \\
\text { poverty }\end{array}$ \\
\hline Poverty threshold & US\$1.25 & US\$1.25 & US\$1.25 & US\$2.00 & US $\$ 2.00$ & US\$2.00 \\
\hline
\end{tabular}

\footnotetext{
${ }^{11}$ It is noted that the Foster-Greer-Thorbecke (1984) (FGT) class of poverty measures are used in our study. The headcount index (P0) measures the proportion of the population that is poor (Haughton and Khandker, 2009, p.67). The poverty gap index (P1) measures the extent to which individuals fall below the poverty line as a proportion of the poverty line, while the squared poverty gap index (P2) averages the squares of the poverty gaps relative to the poverty line (ibid., 2009, p.67).
} 


\begin{tabular}{|c|c|c|c|c|c|c|}
\hline Definition & P0 (headcount) & $\begin{array}{l}\text { P1 } \\
\text { (Gap) }\end{array}$ & $\begin{array}{c}\text { P2 } \\
\text { Gap Squared }\end{array}$ & $\begin{array}{c}\text { P0 } \\
\text { (headcount) }\end{array}$ & $\begin{array}{l}\text { P1 } \\
\text { (Gap) }\end{array}$ & $\begin{array}{c}\text { P2 } \\
\text { Gap Squared }\end{array}$ \\
\hline Model & $\mathrm{FE}$ & $\mathrm{FE}$ & $\mathrm{FE}$ & FE & $\mathrm{FE}$ & $\mathrm{FE}$ \\
\hline \multicolumn{7}{|l|}{ VARIABLES } \\
\hline \multirow[t]{2}{*}{ plogagrivapc } & $-4.019 \star \star \star *$ & $-4.979^{\star \star \star}$ & $-4.032^{\star \star \star}$ & $-3.856^{\star \star *}$ & $-4.532^{\star * *}$ & $-5.012^{\star \star *}$ \\
\hline & (10.44) & (1.184) & (1.211) & $(0.730)$ & $(0.878)$ & (0.995) \\
\hline Observations & 79 & 77 & 74 & 77 & 76 & 76 \\
\hline R-squared & 0.608 & 0.561 & 0.575 & 0.621 & 0.62 & 0.6 \\
\hline Number of code1 & 17 & 17 & 17 & 17 & 17 & 17 \\
\hline Hausman Test $r$ & FE & FE & FE & FE & FE & FE \\
\hline In favour of & & & & & & \\
\hline
\end{tabular}

In Panel B of Table 15.2, we have examined the effect of agricultural value added per capita on urban poverty based on the commercialisation index. Panel B shows that, as the agricultural value added per capita increases, the headcount (only at the poverty line of US\$2.00, not US\$1.25), the poverty depth, and the severity of poverty (at both US\$1.25 and US\$2.00) have been significantly reduced. It is particularly noted that the magnitude of reduction is larger for urban poverty than for rural poverty, implying a substantially larger indirect effect of agricultural transformation on urban poverty, for example, as a positive effect of rural-to-urban migration (e.g. through finding a job in the urban non-farm sector with real wages much higher than in rural areas) exceeds its negative effect (e.g. expanding urban slums with low-paying jobs as a result of migration).

That is, agricultural growth also reduces urban poverty in terms of the share of poor people based on the headcount index (P0). It is also found that agricultural growth decreases depth of urban poverty which is based on the poverty gap index (P1) and inequality among the urban poor based on the squared poverty gap index (p2), a weighted sum of poverty gaps where the weights are the proportionate poverty gaps themselves. For instance, a 1\% increase in agricultural value added is associated with a $2.73 \%$ decrease in the moderate poverty headcount ratio (based on Case 5 of Panel B). A positive externality of agricultural growth is 
an expansion of processing firms in urban areas and thereby employment which then reduces poverty.

In the regression based on the product diversity index $H^{\prime}$, we find similar results with the coefficient estimate statistically significant in all the cases for both rural and urban poverty. That is, if the agricultural production is more diverse, poverty in both rural and urban areas is significantly reduced. ${ }^{12}$

We have estimated the effects of (predicted) agricultural TFP on rural and urban poverty and the overall results remain broadly unchanged. We have found that improvement in agricultural TFP significantly reduces rural poverty. For instance, a 1\% improvement in TFP tends to decrease rural poverty headcount ratio based on US\$1.25 a day by $4.78 \%$, keeping other factors constant. If we combine the first stage and the second stage results, we can infer that a $1 \%$ increase in commercialisation index TFP tends to reduce rural poverty by $0.54 \%$. This appears to be quite large in terms of the absolute magnitude of the effect of increase in TFP on poverty. We have found that a rise in agricultural TFP significantly reduces urban poverty as well. A $1 \%$ increase in TFP tends to decrease the urban headcount ratio based on US\$1.25 a day by $4.02 \%$, keeping other factors constant. If we combine the first stage and second stage results, we can infer that a $1 \%$ improvement in commercialisation index tends to reduce rural poverty by $0.45 \% .^{13}$

We have also examined the effect of (predicted) agricultural value added per capita on poverty and child malnutrition in Table 15.3 where in the first stage the commercialisation index is used as a main explanatory variable. ${ }^{14}$ The poverty-reducing effect of agricultural value added per capita is statistically significant for moderate poverty but not for extreme poverty. Here, if agriculture is transformed and this transformation leads to agricultural

\footnotetext{
${ }^{12}$ The results will be provided on request.

${ }^{13}$ The results will be provided on request.

${ }^{14}$ The results are broadly similar if they are based on the product diversity index as a main covariate.
} 
growth, then the status of child nutritional conditions will improve, for instance, because the household has more agricultural products and food availability will improve, or additional income due to the agricultural growth can be used for food consumption for children.

Table 15.3 Effect of Predicted Agricultural Value added per capita on Poverty and Child Malnutrition

\begin{tabular}{|c|c|c|c|c|c|c|}
\hline & Case 1 & Case 2 & Case 3 & Case 4 & Case 5 & Case 6 \\
\hline VARIABLES & $\begin{array}{c}\text { Poverty } \\
\text { headcount } \\
\text { US } \$ 1.25 \\
\text { Based on } \\
\text { Case } 2 \\
\text { of Table } 2 \\
\text { Trans } \\
\text { Index } \\
\end{array}$ & $\begin{array}{c}\text { Poverty } \\
\text { headcount } \\
\text { US } \$ 1.25 \\
\text { Based on } \\
\text { Case } 5 \\
\text { of Table } 2 \\
\text { Product } \\
\text { Diversity }\end{array}$ & $\begin{array}{c}\text { Poverty } \\
\text { headcount } \\
\text { US } \$ 2.00 \\
\text { Based on } \\
\text { Case } 2 \\
\text { of Table } 2 \\
\text { Trans } \\
\text { Index }\end{array}$ & $\begin{array}{c}\text { Poverty } \\
\text { headcount } \\
\text { US } \$ 2.00 \\
\text { Based on } \\
\text { Case } 5 \\
\text { of Table } 2 \\
\text { Product } \\
\text { Diversity }\end{array}$ & $\begin{array}{l}\text { log Child } \\
\text { Underweight } \\
\text { Based on } \\
\text { Case } 2 \\
\text { of Table } 2 \\
\text { Trans Index }\end{array}$ & $\begin{array}{c}\text { log Child } \\
\text { Underweight } \\
\text { Based on } \\
\text { Case } 5 \\
\text { of Table } 2 \\
\text { Product } \\
\text { Diversity } \\
\end{array}$ \\
\hline Plogagrivapc & $\begin{array}{l}-0.497 \\
(0.825)\end{array}$ & $\begin{array}{l}-0.347 \\
(0.885)\end{array}$ & $\begin{array}{l}-0.897^{\star *} \\
(0.402)\end{array}$ & $\begin{array}{l}-0.803^{*} \\
(0.435)\end{array}$ & $\begin{array}{c}-0.888^{\star \star *} \\
(0.155)\end{array}$ & $\begin{array}{c}-0.653^{\star \star \star} \\
(0.171)\end{array}$ \\
\hline Observations & 142 & 136 & 142 & 136 & 143 & 126 \\
\hline R-squared & 0.248 & 0.241 & 0.324 & 0.305 & 0.743 & 0.77 \\
\hline Number of code 1 & 18 & 15 & 18 & 15 & 18 & 15 \\
\hline $\begin{array}{l}\text { Hausman Test } \\
\text { in favour of }\end{array}$ & $\mathrm{FE}$ & $\mathrm{FE}$ & $\mathrm{FE}$ & $\mathrm{FE}$ & $\mathrm{FE}$ & $\mathrm{FE}$ \\
\hline
\end{tabular}

Our results suggest that agricultural growth tends to reduce child underweight prevalence. That is, a $1 \%$ of growth in agricultural value added per capita tends to reduce child underweight prevalence by $0.65 \%$ to $0.89 \%$. If the first and the second stage results are combined, we can infer that agricultural growth reduces child underweight prevalence by $0.07 \%$ to $0.10 \%$. It is noted that this is an annual estimate and the commercialisation will have a substantial impact on child nutrition over time. ${ }^{15}$

Finally, we have examined the relationship between agricultural value added per capita and inequality by replacing poverty in the second stage by inequality. We have used log of Gini coefficients for rural areas (called 'rural Gini) and for urban areas (called 'urban Gini). However, in none of the cases (predicted) log of agricultural value added per capita is statistically significant in explaining variation in inequality. This could be due to either the fact that agricultural transformation or agricultural growth does not reduce inequality or a

\footnotetext{
${ }^{15}$ This is of course subject to the caveat that intra-household distribution of income and food is often not equitable (Dreze and Sen, 1995).
} 
non-linear relationship between rural Gini and agricultural value added per capita. So we examined whether there is any nonlinear relationship between agricultural value added per capita and its square and found that statistically significant coefficients are found only for rural Gini when we restrict the sample to low-income countries only. We have found that as the agricultural sector grows, inequality of low-income countries tends to fall, but if it further grows beyond a certain point, inequality tends to increase. So the inequality-reducing effect of the agricultural growth (induced by commercialisation) is observed only at the initial stage of development. This may be due to the strong poverty- reducing effect at the lower poverty threshold than at the higher poverty threshold for rural areas.

\subsection{Concluding Remarks}

This chapter has analysed the dynamics of transformation of agriculture in rural Asia and the Pacific with a focus on its effect on poverty, based on the up-to-date country panel dataset for the region. We have examined the effects of agricultural transformation, on various measures of poverty and inequality where the dynamic effect of agricultural transformation on agricultural growth is modelled by a dynamic panel model and then poverty is estimated by the predicted agricultural value added per capita using the static panel model. Agricultural transformation is defined by three different indices, namely, agricultural openness index, commercialization index to capture the share of processed agricultural and livestock production in the total production, and the agricultural production diversity index based on how agricultural production is diversified into different products. Our study is important because, as far as we know, this is the first study to quantify the agricultural transformation albeit in a limited manner - and evaluate its effect on agricultural output, growth, and productivity in the Asian and Pacific context. We have also assessed the effect of these terms on rural and urban poverty and on inequality in Asia using cross-country panel data. 
Transformation of the agricultural sector in terms of commercialisation and product diversity has dynamically increased agricultural value added per capita and consequently reduced both rural and urban poverty significantly. Our results show that even a small change in the process of agricultural transformation, such as a $1 \%$ increase in commercialisation index or in product diversity index, reduces both rural and urban poverty substantially. However, the effect of agricultural openness has not significantly impacted on agricultural growth. ${ }^{16}$ Presumably, this is linked to slow adaptation to growing competitiveness of integrated markets. The effect of agricultural transformation in reducing child malnutrition has also been observed, while inequality in rural areas is reduced only at the initial stage of development of agriculture for low-income countries. As an extension, we have examined the effect of agricultural transformation on TFP. Our analysis confirmed that agricultural transformation, in terms of commercialisation and product diversification, has promoted TFP with lags. This reinforces the positive relationship between agricultural value added and agricultural transformation. We have also found that the predicted TFP significantly reduced rural and urban poverty. ${ }^{17}$

Some policy implications are delineated below. First, there is a case for promoting synergy between public and private investment in rural areas. A priority is to strengthen rural infrastructure. Although our analysis does not focus on smallholders, their inclusion in the transformation process through easier access to credit, land and output markets and upgradation of product quality could lead to significantly larger poverty and inequality reduction. As prospects of absorption of growing rural labour force in manufacturing and services and other activities are limited, it is important for policymakers to create enough jobs in rural areas (e.g. through expanding Rural National Employment Guarantee Schemes in

\footnotetext{
${ }^{16}$ One possibility is that that agricultural openness effect is manifested through agricultural commercialisation and product diversity.

${ }^{17}$ Barrett et al. (2017) argues that ending extreme poverty will require structural change in agriculture sectors in Sub-Saharan Africa. Future research should extend our research to all developing countries.
} 
remote areas). Some of the preceding proposals would help create more employment in rural areas, raise wage rates and dampen rural-urban migration. Land rental markets would facilitate the redistribution of land in favour of more efficient small farmers and help consolidation of small farms into more viable units. Finally, in view of the demographic transition, expansion of education and training facilities in rural areas would help reap the dividend flowing from a larger workforce.

\section{References}

Barrett, C. B., M. E. Bachke, M. F. Bellemare, H. C. Michelson and S. Narayanan (2012) 'Smallholder Participation in Contract Farming: Comparative Evidence from Five Countries’ World Development, 40(4), pp.715-730.

Barrett, C. B., Christiaensen, L., Sheahan, M. and Shimeles, A. (2017) 'On The Structural Transformation of Rural Africa', Policy Research Working Paper 7938, The World Bank, Washington D.C.

Bloom, D. E., Canning, D., Fink, G., Finlay, J. (2007). 'Realizing the Demographic Dividend: Is Africa any different?’ PGDA Working Paper No. 23, Harvard University.

Blundell, R., and S. Bond (1998). Initial conditions and moment restrictions in dynamic panel data models.Journal of Econometrics 87: 115-143.

Dawe, D., (2015). 'Agricultural transformation of middle-income Asian economies: diversification, farm size and mechanization', Korea, 6(7.5), pp.1-6.

Dreze, J., and Sen, A. K., (1995). India Economic Development and Social Opportunity, Oxford University Press, New Delhi.

Foster, J., Greer, J., \& Thorbecke, E. (1984). ‘A class of decomposable poverty measures’, Econometrica, 32(3) pp. 761-766. 
Fuglie, K. O. (2012). 'Productivity Growth and Technology Capital in the Global Agricultural Economy.’ In: Fuglie K., Wang, S.L. and Ball, V.E. (eds.) Productivity Growth in Agriculture: An International Perspective. CAB International, Wallingford, UK, pp. 335-368.

Fuglie, K. O. (2015). ‘Accounting for Growth in Global Agriculture,' Bio-based and Applied Economics, vol. 4 (December).

Haughton, J., and Khandker, S. R. (2009). Handbook on Poverty and Inequality, World Bank, Washington, DC..

IFAD (2016). Rural Development Report 2016: Fostering inclusive rural transformation, IFAD, Rome.

Imai, K. S. (2017). 'Roles of Agricultural Transformation in Achieving Sustainable Development Goals on Poverty, Hunger, Productivity, and Inequality', RIEB Discussion Paper Series, No. DP2017-26, Kobe University.

Imai, K. S., Abekah-Nkrumah, G., and Purohit, P. (2014) 'Is Rural Contribution to Aggregate Poverty Reduction Substantial? New Evidence', Brooks World Poverty Institute Working Paper Series 208/14, BWPI, The University of Manchester.

Reardon $\mathrm{T}$ and Timmer CP. (2014). "Five Inter-Linked Transformations in the Asian Agrifood Economy: Food Security Implications.” Global Food Security 3(2): 108-117.

Ravallion, M., Chen, S., and Sangraula, P. (2009). “Dollar a Day Revisited,” World Bank Economic Review, 23(2), pp.163-184.

Remans, R., Wood, S. A., Saha, N., Anderman, T. L,, DeFries, R. S., (2014). 'Measuring nutritional diversity of national food supplies’, Global Food Security, 3(3-4), pp.174182.

Thapa, G. (2016) 'Land Markets in Asia: A Synthesis of Issues, Lessons and Policy Implications', APR, IFAD. 
Windmeijer, F. (2005). 'A finite sample correction for the variance of linear efficient twostep GMM estimators’. Journal of Econometrics, 126: 25-51.

World Bank (2015). Staying the Course: World Bank East Asia and Pacific Economic Update October 2015, Washington DC., The World Bank. 